\title{
DESCRIPTIVE PROFILE OF BODY STRUCTURE OF TOP GRECO-ROMAN STYLE WRESTLERS DEFINED WITH METHOD OF MULTICHANNEL BIOELECTRIC IMPEDANCE
}

\author{
Goran Kasum $^{1}$ and Milivoj Dopsaj ${ }^{1}$
}

${ }^{1}$ Faculty of Sports and Physical Education, University of Belgrade, Serbia

\section{SUMMARY}

Because of the specificity of given sport and weight categories wrestlers are characterized by specific morphologic characteristics. With the development of new measurement technologies there are some new opportunities for the development of new ways of obtaining information relevant to the sports system. One of the new technologies, which are used in area of measurement of body composition structure, is a method of bioimpedace, and the latest generations use a variant of the multichannel bioelectrical bioimpedance. The goal of this study is to define morphological model of top senior wrestlers by using the latest technological methods that will revalidate the existing knowledge about the given area. The sample of respondents is made of 22 male wrestlers, Greco-Roman style, top senior level athletes from four different countries: Serbia $(n=10)$, Croatia $(n=9)$, Montenegro $(n=2)$ and Greece $(n=1)$. Measurement of body composition is made with method of multichannel bioelectric impedance with professional apparatus of latest generation - InBody 720 Tetrapolar 8-Point Tactile Electrode System (Biospace, Co., Ltd). The most important result of this research is definition of generic (general) four-dimensional model (4D model) of body composition with quality international level wrestlers with following characteristics: in regards to average body mass of sample wrestlers $-81.95 \mathrm{~kg}$, the amount of water is $55.08 \mathrm{~L}$ or $67.24 \%$, the amount of proteins is $15.00 \mathrm{~kg}$ or $18.33 \%$, minerals $4.98 \mathrm{~kg}$ or $5.97 \%$ and fat mass $6.99 \mathrm{~kg}$ or $8.49 \%$.

Key Words: Greco-Roman style wrestlers, bioimpedace, body composition, model.

\section{INTRODUCTION}

The majority of experts and scientists dealing with morphology of athletes consider that there is a dialectic connection between particular sports and morphological characteristics of the one athlete. Namely, in majority of cases, young athletes choose sports adequate to their morphology, because that morphology is the fact that in certain amount determines his body advantage. On the other hand, by practicing the chosen sport, and considering the phenomena of adaptation to certain sports exertion, the athlete gains characteristics typical for given sports. It was shown that as higher the sports achievements are, the tighter is their connection to athlete`s body composition (Bajić, Ponorac, Rašeta, \& Bajić, 2010;
Obradović, Jakšić, Matić, Milošević, Bubanj, \& Bubanj, 2011; Yoon, 2002). That is why the significant attention in majority of sports is given to research of anthropological status of active athletes, as also to those who have the intention of doing some of the sports (Khani, Farokhi, Shalchi, Angoori, \& Ansari, 2011; Rupčić, Matković, Knjaz, Baščevan, \& Rodić, 2011; Schmidt, Piencikowski, \& Vandervest, 2005). Knowing of individual characteristics of active wrestlers is necessary precondition for successful planning of quality programs for management of training process (Станков, КАимин, \& Письмеский, 1984). Among many characteristics owned by every athlete, the morphological ones are, for sure, one of those that significantly influence the achievement of significant sports results. That is why they are recorded 
and analysed with special attention, as a base or morphological status at the very beginning of training process, but also as a goal, e.g. morphological status that needs to be achieved (Kasum \& Obradović, 2008).

Wrestlers are characterized by specific morphological characteristics, which basic features are: accentuated width and girth of the body, proportionally long arms and short legs, a large percentage of active muscular body weight (Борисов і Туманян, 1973). By classification of Bunaka (Станков et al., 1984), there are three basic constitutional types of fighters (chest, muscular and abdominal), and four transition (breastbone - muscular, muscular - thorax, muscular - belly and belly - muscular). Chest type fighters are characterized by well-developed chest and powerful shoulder belt. Muscular type is characterized by cylindrical shape of the chest, flat stomach and a strong, well-developed muscles and moderate fat deposits. Abdominal type is characterized by a conical shape of the chest, bulging stomach, his back bent, significant amount of fat and medium musculature. There are a number of morphological parameters that are monitored and analyzed which can significantly affect the choice of technique that is most often used in combat (Kasum \& Radovic, 2009). This primarily refers to the longitudinal and transverse dimensions of the skeleton and the diameters of the joints, which are to a large extent determined by hereditary factors. However, it was observed that the biggest wrestling competition winners, compared to other competitors of the same weight category, often have more accentuated longitudinal dimensions (Kasum, 2001).

Influence of long term training process on some morphological parameters can be significant, but they cannot significantly be influenced by planning. This is the case with osseous system, where the wrestlers, under the influence of stress, obtained higher specific gravity, and volume (Аныш, 1999). It was observed that the champions of Europe, World and Olympic games differ from other wrestlers from the team by the fact that they have greater absolute and relative size of the bone and muscle tissue, and the smaller size of subcutaneous and total internal fat. Similar results were obtained by Туманян and Мартиросов (1974), and they believe that such a relationship of components of the body weight predisposes appropriate specific body weight of wrestlers, which is the largest in representatives of smallest weight classes, and the lowest with representatives of heavyweights.

There are several different formulas to calculate body composition. All of them use data obtained by anthropometric measurements. In this way are obtained values of muscle, bone and fat tissue in absolute and relative values. Thus Моргунова, Патратия, and Старков (1985), based on a sample of 138 freestyle wrestlers from the structure of the SSSR national team, using the formula I. Matiegka, made a table of basic parameters of body composition of wrestlers in preparation and competition period. They found that the absolute values of muscle, bone and fat tissue growth from the lowest to highest weight categories, while the mean relative values of muscle tissue in wrestlers range from 48.37 to $52.5 \%$ (minimum 43.67, maximum $56.46 \%$ ), the mean relative values of bone tissue from $14.2 \%$ to 16.92 (12:39 minimum, maximum $23.88 \%$ ), and the mean relative values of fat from 8.44 to $17.43 \%$ (minimum 5.57 , maximum $27.44 \%$ ). The same authors found that the percentage of body fat increases from the lowest to the highest weight categories, the percentage of bone tissue decreases with weight of tested wrestlers, while the percentage of muscle tissue did not reveal any clear principle. Comparing the 12 parameters of body composition of wrestlers, of which 7 are indicators of absolute and 5 indicators of varying values, it was found that in all 12 indicators of the morphological status there are some differences between the values obtained during the preparation and competition period. However, statistically significant differences were found only for values of absolute and relative amounts of body fat, for the values for total amount of fat in the body, as well as for the relative values of muscle tissue.

The development of new measurement technologies opens new possibilities for the development of new ways of obtaining information relevant to the sport system. One of the new technologies used in space measurement of body composition structure is a method bioimpedance and the latest generation use multichannel bioelectrical bioimpedance variation, as a method that is becoming the gold standard in studies of human morphology (InBody 720 Biospace, 2008).

The aim of this research is to define morphological model of senior age wrestlers, using the latest technological methods that will make revalidation of existing knowledge about the given area.

\section{METHODS}

\section{Sample of respondents}

The sample was composed of 22 male respondents competing in the discipline of Greco-Roman style of 
wrestling at the elite senior level. Respondents were members of representations of following countries: Serbia $(n=10)$, Croatia $(n=9)$, Montenegro $(n=2)$ and Greece $(n=1)$. All were familiar with the testing conditions and they voluntarily participated in the study. Basic descriptive characteristics of the sample were: Age $=23.1 \pm 2.4$ yrs., $\mathrm{BH}=175.7 \pm 8.96 \mathrm{~cm}$, $\mathrm{BM}=81.95 \pm 14.75 \mathrm{~kg} ., \mathrm{BMI}=26.33 \pm 2.43 \mathrm{~kg} / \mathrm{m}^{2}$., Training Experience $=12.5 \pm 2.7$ yrs., weekly training frequency $=9.5 \pm .9$ training session / week., the summary volume of weekly training mode $=842.4$ \pm 139.2 min workouts / week. The research was carried out in accordance with the conditions of »Declaration of Helsinki for recommendations guiding physicians in Biomedical Research Involving Human Subjects« - (http://www.cirp.org/library/ethics/ helsinki/), and with the approval and consent of the Ethics Committee of the Faculty sport and Physical education, University of Belgrade.

\section{Testing procedures}

Measurement of body composition was performed using bioelectrical impedance (Bioelectrical Impedance Analysis - BIA), using the latest generation of professional appliances - InBody 720 Tetrapolar 8-Point Tactile Electrode System (Biospace, Co., Ltd.). InBody 720 apparatus uses the latest technology of measuring body composition using DSM-BIA method (Direct Segmental Multi-frequency Bioelectrical Impedance Analysis), where the use of a different frequency range from $1 \mathrm{kHz}$ to $1 \mathrm{MHz}$ using methods reactivity measures quantity / weight of all four major body components - water, proteins, minerals and fats with accuracy of: $92.2 \%$ for Visceral fat Area (VFA) to $98.0 \%$ for the Fat Free Mass (FFM) (720 InBody Biospace, 2008).

All measurements were carried out in the period March - April 2010, during the final stages of preparation for the European Championship in wrestling, and the respondents were familiar with all preconditions of measurement procedures (ACSM, 2005; Heyward, 2006; InBody 720 Biospace, 2008):

- measurements were carried out in the morning (between 9:00 and 10:00 a.m.); evening before measurements respondents were not taking any food after 9:00 p.m., and on the day of measurement they were not eating breakfast or drinking liquids before the end of the measurement procedure;

- 12 hours before measurements respondents did not have great physical strain, i.e. practice strains; before measurements respondents performed all basic physiological needs;
- 48 hours before the measurement the respondents were not consuming alcohol; before the measurement the respondents were standing at least 5 minutes to redistribute the body fluids in the tissues; the measurement was performed in the standing position by the procedure recommended by the manufacturer (hands aside 150 from the body).

\section{Variables}

This study comprises a total of 23 variables, of which 13 are primary and 10 are derived (index) variables which define the morphology and composition of the body:

Basic variables to define the morphological structure and body composition were:

- $\mathrm{TM}$ - body mass, expressed in kg;

- BMI - body mass index, expressed in $\mathrm{kg} / \mathrm{m}^{2}$;

- ICW - intra cellular water, expressed in L;

- ECW - extra cellular water, expressed in L;

- TBW - total body water, expressed in L;

- Proteins, expressed in kg;

- Minerals, expressed in kg;

- BMC - bone mineral content, expressed in kg;

- BFM - body fat mass, expressed in kg;

- SMM - skeletal muscle mass, expressed in kg;

- BCM - body cell mass, expressed in kg;

- VFA - visceral fat area, expressed in $\mathrm{cm}^{2}$;

- Fitness_SCORE, body composition score expressed as numerical equivalent.

Derived (index) variables to define morphological structure and body composition were:

- TBW $\%$ - percent of total body water, calculated as: TBW / BM, expresed in \%;

- Proteini $\%$, percent of proteins, calculated as: Proteini / BM, expresed in \%;

- $\mathrm{BMC} \%$ - percent of BMC, calculated as: BMC / BM, expresed in \%;

- PBF - percent of body fat, calculated as: BFM / BM, expresed in \%;

- SMM $\%$ - percent of smooth muscle mass index, calculated as: SMM / BM, expresed in \%;

- $\mathrm{BCM} \%$ - percent of body cell mass, calculated as: $\mathrm{BCM} / \mathrm{BM}$, expresed in \%;

- PFI - protein fat index, calculated as relation between Protein and Body Fat Mass, expresed in $\mathrm{kg}$;

- BSI - bone strength index, calculated as relation between BMC and BM, expresed in $\mathrm{g} / \mathrm{kg}$;

- $\mathrm{BMI} / \mathrm{PBF}$ index - calculated as relation between BMI and PBF, expresed in $\mathrm{kg} / \mathrm{m}^{2}$ per $1 \%$ of fat; 
- Fat Distribution Index (VFA/BF) as relation between VFA and BF, expresed in $\mathrm{cm}^{2}$ of visceral fat per $1 \mathrm{~kg}$ of body mass fat.

\section{Statistical analysis of data}

All results were first subjected to descriptive statistical analysis to define the basic measures of central tendency and dispersion of data $(\mathrm{M}, \mathrm{SD}, \mathrm{cV} \%, \mathrm{SE}$, 95\% confidence interval - lower and upper bound). For the form of distribution were used measures of flatness and curvature (skewnis and kurtosis), while for calculating the regularity of distribution was used a non-parametric Kolmogorov-Smirnov test. All statistical analyzes were implemented using software SPSS Statistics 17.0. (SPSS Statistics, Inc.).

\section{RESULTS}

\section{Results of basic morphological variables}

Results of basic descriptive statistics and comparative analysis of partial morphological variables measured by sample respondents (Wrestlers $/ n=22$ ), are shown in Table 1.

\section{The results of derived [index] morphological variables}

Results of basic descriptive statistics of derived (index) morphological variables measured on samples of respondents $(\mathrm{W} / n=22)$ are shown in Table 2 .

TABLE 1

Indicators descriptive statistics basic morphological variables measured by sample respondents.

\begin{tabular}{|c|c|c|c|c|c|c|c|c|c|c|c|}
\hline \multirow{2}{*}{ Varibales } & \multirow{2}{*}{ M } & \multirow{2}{*}{$S D$} & \multirow{2}{*}{$c V \%$} & \multirow{2}{*}{ Min } & \multirow{2}{*}{ Max } & \multirow{2}{*}{ Skew } & \multirow{2}{*}{ Kurt } & \multirow{2}{*}{ SE } & \multicolumn{2}{|c|}{$\begin{array}{l}95 \% \text { Confidence } \\
\text { Interval }\end{array}$} & \multirow{2}{*}{$\mathrm{K}-\mathrm{S} p$} \\
\hline & & & & & & & & & $\begin{array}{l}\text { Lower } \\
\text { Bound }\end{array}$ & $\begin{array}{l}\text { Upper } \\
\text { Bound }\end{array}$ & \\
\hline TM (kg) & 81.95 & 14.39 & 17.56 & 61.50 & 118.20 & .66 & .42 & 3.07 & 76.60 & 87.30 & .852 \\
\hline BMI $\left(\mathrm{kg} / \mathrm{m}^{2}\right)$ & 26.33 & 2.37 & 9.00 & 21.78 & 31.25 & .33 & .34 & .51 & 25.34 & 27.33 & .850 \\
\hline ICW (L) & 34.71 & 6.10 & 17.57 & 26.10 & 52.80 & 1.12 & 2.46 & 1.30 & 32.58 & 36.84 & .728 \\
\hline ECW (L) & 20.37 & 3.83 & 18.80 & 15.50 & & 99 & & .82 & & & \\
\hline TBW (L) & 55.08 & 9.91 & 17.99 & 41.80 & 84.00 & 1.08 & 2.17 & 2.11 & 51.63 & 58.53 & .816 \\
\hline Proteins $(\mathrm{kg})$ & 15.00 & 2.62 & 17.47 & 11.30 & 22.80 & 1.13 & 2.52 & .56 & 14.06 & 15.91 & .731 \\
\hline Minerals $(\mathrm{kg})$ & 4.89 & .99 & 20.25 & 3.60 & 7.77 & .99 & 2.03 & .21 & 4.55 & 5.24 & .927 \\
\hline BMC (kg) & 4.00 & .83 & 20.75 & 2.87 & 6.39 & .98 & 1.87 & .18 & 3.71 & 4.29 & .986 \\
\hline BFM (kg) & 6.99 & 3.28 & 46.92 & 2.30 & 17.00 & 1.18 & 2.89 & .70 & 4.74 & 9.23 & .942 \\
\hline SMM (kg) & 43.26 & 7.96 & 18.40 & 32.00 & 66.90 & 1.12 & 2.48 & 1.70 & 40.50 & 46.02 & .722 \\
\hline BCM (kg) & 49.71 & 8.73 & 17.56 & 37.40 & 75.60 & 1.11 & 2.44 & 1.86 & 46.67 & 52.76 & .723 \\
\hline VFA $\left(\mathrm{cm}^{2}\right)$ & 46.60 & 20.11 & 43.15 & 20.20 & 95.40 & .76 & .12 & 4.29 & 36.57 & 56.64 & .935 \\
\hline Fitness_SCORE & 96.90 & 8.11 & 8.37 & 85.00 & 120.00 & 1.06 & 2.06 & 1.73 & 93.05 & 100.00 & .545 \\
\hline
\end{tabular}

Legend: M - Mean; SD - Standard deviation; cV\% - Coefficient of variation in percent; Min - Minimum; Max - Maximum; Skew - Skewness; Kurt - Kurtosis; SE - Standard eror; K-S p - Kolmogorov-Smirnov probability; TM - Body weight; BMI - Body mass index; ICW - Intracellular water; ECW - Extracellular water; TBW - Total body water; BMC - Bone mineral content; BFM - Body fat mass; SMM - Skeletal muscle mass; BCM - Body cell mass; VFA - Visceral fat area.

\section{DISCUSSION}

On a general level, adequate body composition is one of the factors that have a significant degree of influence in terms of selection of preferential techniques and the formation of a specific wrestling style (Kasum \& Radovic, 2009), and achieving competitive success at major competitions (Jagiełło \& Krusze- wski, 2005; Jagiełło, Tkaczuk, \& Kruszewski, 2004). Given effect in certain sports is even more important, especially in those sports where there are weight classes, i.e. martial arts and strength sports such as lifting weights (Jagiello \& Kruszewska, 2009).

Advancement of technology itself evolves development of new measurement instruments, which 
TABLE 2

Basic descriptive statistics derived (index) morphological variables measured by samples respondents.

\begin{tabular}{|c|c|c|c|c|c|c|c|c|c|c|c|}
\hline \multirow{2}{*}{ Varibales } & \multirow{2}{*}{$M$} & \multirow{2}{*}{$S D$} & \multirow{2}{*}{$c V \%$} & \multirow{2}{*}{ Min } & \multirow{2}{*}{$\operatorname{Max}$} & \multirow{2}{*}{ Skew } & \multirow{2}{*}{ Kurt } & \multirow{2}{*}{ SE } & \multicolumn{2}{|c|}{$\begin{array}{l}\text { 95\% Confidence } \\
\text { Interval }\end{array}$} & \multirow{2}{*}{$\mathrm{K}-\mathrm{S} p$} \\
\hline & & & & & & & & & Lower & Upper & \\
\hline TBW\% \% (\%) & 67.24 & 2.51 & 3.73 & 60.91 & 71.41 & -.42 & .76 & .54 & 65.61 & 68.88 & .658 \\
\hline Proteins $\%(\%)$ & 18.33 & .70 & 3.84 & 16.46 & 19.62 & -.46 & 1.25 & .15 & 17.86 & 18.79 & .779 \\
\hline BMC\% $\%$ (\%) & 4.86 & .24 & 4.96 & 4.45 & 5.41 & .41 & .10 & .51 & 4.73 & 4.98 & .965 \\
\hline $\mathrm{PBF} \%(\%)$ & 8.49 & 3.36 & 39.58 & 2.95 & 17.17 & .42 & 1.03 & .72 & 6.28 & 10.70 & .579 \\
\hline SMM \% (\%) & 52.79 & 2.06 & 3.90 & 47.78 & 56.79 & .44 & -.03 & .96 & 51.45 & 54.13 & .658 \\
\hline BCM $\%(\%)$ & 60.74 & 2.32 & 3.82 & 54.75 & 65.13 & -.34 & 1.02 & .50 & 59.19 & 62.30 & .884 \\
\hline PFI (\%) & 2.69 & 1.54 & 57.30 & .96 & 6.65 & 1.60 & 1.82 & .33 & 2.18 & 3.21 & .051 \\
\hline BSI (\%) & .0486 & .0024 & 4.94 & .0445 & .0541 & .41 & .10 & .0005 & .047 & .05 & .965 \\
\hline $\mathrm{BMI} / \mathrm{PBF}$ index $(\%)$ & 3.79 & 2.11 & 55.68 & 1.82 & 9.70 & 1.89 & 2.90 & .45 & 3.11 & 4.47 & .056 \\
\hline VFA/BF (\%) & 7.267 & 2.959 & 40.73 & 2.802 & 17.000 & 2.02 & 5.44 & .631 & 6.30 & 8.23 & .174 \\
\hline
\end{tabular}

Legend: $\mathbf{M}$ - Mean; SD - Standard deviation; cV\% - Coefficient of variation in percent;

Min - Minimum; Max - Maximum; Skew - Skewness; Kurt - Kurtosis; SE - Standard eror; K-S p - Kolmogorov-Smirnov probability; TBW\% - Percent of total body water; Proteins $\%$ - Percent of proteins; BMC $\%$ - Percent bone mineral content; $\mathbf{P B F} \%$ - Percent of body fat; SMM\% - Percent of smooth muscle mass index; BCM\% - Percent of body cell mass; PFI - Protein fat index; BSI - Bone strength index; VFA/BF - Fat distribution index.

has resulted in the establishment of such new instruments and measurement procedures, which all together establishes the basis for a new understanding potential with the possibility to improve the existing level of knowledge. The aim of this study was to use this new technology - multi-channel electrical bioimpedance, and by that define a generic / general/ descriptive profile of body composition of elite Greco-Roman style wrestlers, as well as to establish new indicators defined as index values for the evaluation of the same.

The results showed that distribution of all analysed variables is not different from the hypothetical correct one, and therefore it can be argued that the results can be interpreted as valid and reliable, regardless of whether it is original or derivative (index) variables (Table 1 and 2, from K-S $p=.986$ for Osseous to $p$ $=.051$ for PFI).

In relation to body mass (TM) measured average value of tested sample was $14.39 \pm 81.95 \mathrm{~kg}$ with a range of scores from 61.5 to $118.2 \mathrm{~kg}$. As the test sample was made up of wrestlers from all weight categories, data on the average weight is only informative.

In relation to body mass index (BMI) measured average value of tested sample was $26.33 \pm 2.37 \mathrm{~kg} /$ $\mathrm{m}^{2}$ with limit values from 21.78 to $31.25 \mathrm{~kg} / \mathrm{m}^{2}$. On the basis of the reliability interval ( $95 \%$ probability) it can be argued that elite wrestler`s optimal BMI values are in the range of 25.34 to $27.33 \mathrm{~kg} / \mathrm{m}^{2}$. Bearing in mind the fact that the tested sample is comprised of top level wrestlers from four regional countries (Serbia, Croatia, Montenegro and Greece) it can be accepted as a fact that the given range of BMI is competitive optimum in relation to quantitative characteristics of body mass for Balkan region population of wrestlers.

Data about the amount of fluid inside the body (Tables 1 and 2) showed that the average hydration measures of tested wrestlers were at a level of 34.71 \pm 6.10 liters of liquid content in the cells (ICW), 20.37 \pm 3.83 liters of liquid contents in the extracellular space $(\mathrm{ECW})$, that the total amount of water in the body was at the level of $55.08 \pm 9.91$ liters of total fluid in the body (TBW). Measured amount of TBW represented $67.24 \pm 2.51 \%$ of total body weight (TBW\%). Given variable had the characteristics of a very homogeneous size with minimal variation of only $3.73 \%$, a very small error in measurement methods of only $0.54 \%$ and a reliability interval of 65.61 to $68.88 \%$.

In any case, the amount of water is very important information for wrestlers. Excessive loss of fluids 
leads to dehydration of the body, and each dehydration leads to the loss of electrolytes. Electrolytes that are actually dissolved ions in the liquid, have the function of nerve impulse delivery and shortening of muscles, i.e. all physiological functions. As the fluid enters the body through the gastrointestinal tract, and eliminates through the sweat glands and kidneys, the body (especially the kidneys) makes an effort to preserve the proper concentration of electrolytes. However, if the dehydration process is too fast, violent or too long, the concentration of the electrolyte is more disrupting. Even a little disruption of electrolyte balance is manifested by general weakness, impaired mental function and loss of muscular coordination. The excessive dehydration of organism disrupts the function of the kidney, and therefore leads so reduction in the volume of blood and the loss of intracellular liquids.

In relation to the variable status of contractile tissue (protein and skeletal muscles), the results showed that the measured average protein value is $15.00 \pm$ $2.62 \mathrm{~kg}$, with a range from minimum of 11.30 to a maximum of $22.80 \mathrm{~kg}$, and a reliability interval of 14.06 to $15.9 \mathrm{~kg}$ of proteins weight. In relation to the established skeletal muscle mass (SMM) the average value of the sample was $43.26 \pm 7.96 \mathrm{~kg}$ with a range from a minimum of 32.00 and a maximum of 66.90 $\mathrm{kg}$, and a reliability interval of 40.50 to $46.02 \mathrm{~kg}$ of skeletal muscle mass. The value of the percentage of protein in the body (Proteins $\%$ ) was at the level of $18.33 \pm .70 \%$ proteins $/ \mathrm{kg}$ TM (reliability interval $=$ $17.86-18.79 \%$ ), while in relation to the tested sample of elite wrestlers the percentage of skeletal muscle was $52.79 \pm 2.06 \% \mathrm{SMM} / \mathrm{kg}$ TM (reliability interval $=51.45-54.13 \%$ ). As a measure of the ratio of protein and fat component an innovative index (PFI) was used in this study, and it was found that top wrestlers at $1 \mathrm{~kg}$ of adipose tissue have $2.69 \mathrm{~kg}$ of protein mass, i.e. the given value of the index was at a level of $2.69 \pm 0.70 \%$ proteins/BFM with a reliability interval from 2.18 to $3.21 \%$.

Bearing in mind the fact that in wrestling there are weight classes, aspiration of all wrestlers to have a greater percentage of muscle tissue cannot be realized with forced muscle hypertrophy. In fact, even gain of lean muscle mass can be a problem if the wrestlers are brought into a situation to have to change competitor category. So in training of wrestlers strength training based on the improvement of neurogenic factors must be dominant, which aims to enable the greatest number of motor units with best frequency of the discharge. That is achieved by higher intensity and lesser extent of training. In doing so, it is neces- sary to use the same training exercises for different muscle groups, but also use distinct exercises for the same muscle groups. In this way we get musculature typical for wrestlers, characterized by a strong tendon and not too hypertrophied muscles. A big problem is the loss of muscle mass during weight reduction. It is known that muscles have a three times higher specific weight than fat, so weight loss is often not a true indicator of the efficiency of the reduction of body weight. It happens that the wrestlers lose more than 8 pounds and that their percentage of body fat increases, which is best illustrated by the fact that the regulation of weight was constructed without taking into account some basic principles. This research has also registered a case of wrestlers who lost even 9.6 $\mathrm{kg}$ in weight, and thereby »failed« to increase the absolute value of fat for $.1 \mathrm{~kg}$, respectively to increase the amount of fat by $.7 \%$. Such a pronounced weight loss was caused by loss of 7.1 liters of water, or even $5.4 \mathrm{~kg}$ of lean muscle mass. Of course, the result of such a regulation of weight is participation at the competition, which is not worth mentioning.

It has already been established that with wrestlers as athletes are dominated highly developed contractile characteristics (different aspects of expressing muscle force and muscle strength characteristics) as an adaptive response to training and competition with expressed mesomorphic constitution, i.e. expressed musculature - the muscle component. Consequently, the aforementioned adaptation, besides muscle component reflects to the oily component as well, where it was established that during the competitive part of the season, the percentage value of body fat (PBF) at the top wrestlers is in the range of 4 to $10 \%$, with the exception of the super heavyweight category in which there is a large degree of diversity in the given variable (Yoon, 2002). Almost same results of PBF were determined in this study, because the average value of the given variable was $8.49 \pm 3.36 \%$ $\mathrm{BF} / \mathrm{BM}$ with a reliability interval from 6.28 to $10.70 \%$. In relation to the total value body fat in the organism the average of tested wrestlers was at the level of only $6.99 \pm 3.28 \mathrm{~kg}$ with a reliability interval of 4.74 to $9.23 \mathrm{~kg}$. The average value of visceral fat was 49.71 $\pm 8.72 \mathrm{~cm}^{2}$ (reliability interval $=36.57$ to $56.64 \mathrm{~cm}^{2}$ ), while the average values of two index variables (BMI/ $\mathrm{PBF}$ index and VFA/BF), as indicators of fat distribution in the body (Deurenberg, 2001) were at a level of $3.79 \pm 2.11 \mathrm{~kg} / \mathrm{m} 2$ per $1 \%$ of fat, and $7.267 \pm$ $2.959 \mathrm{~cm} 2$ of visceral fat per $1 \mathrm{~kg}$ of body fat mass, respectively (Table 2).

It is known that the prolonged duration stresses (more than 30 minutes), as well as moderate intensi- 
ty, with pulse of $60-70 \%$ from the maximum, even $85 \%$ of energy derives from fat (Đorđevic, 2005). This fact is the reason why the competition meso-cycle training of wrestlers often includes intensities of moderate loads that are not characteristic for the wrestling match. It is already common for wrestlers who seriously reduce their weight to run in circles around the halls in which they had previously solved the technical and tactical tasks at the end of their training. Of course, a load of greater intensity also includes fat as an energy source, but it is a smaller percentage of energy obtained in that way, but with pulse of $80 \%$ from maximum, only $50 \%$ of energy is gained from fat. In each case, the percentage of body fat should be minimized, and the data obtained from the sample of high-quality wrestlers may represent reference values and some kind of recommended values. These indicators may vary during the year and are slightly lower in the competition than pre-competition mesocycle, but these differences are usually not statistically significant (Schmidt et al., 2005).

However, when the weight of competition mesocycle is compared with the weights in the transition period, statistically significant differences were stated (Buford, Rossi, Smith, O'Brien, \& Pickering, 2006). In the transition period certain relaxation is possible in the control of body weight, but the deviation from the standard weight ought not to be too large, because the process of burning fat in the body requires gradualness and time. It is recommended that the removal of fat per week is between 1.2 and 2 kilograms, and in this period athletes should take food without fat, which contains minerals and vitamins, especially the B complex, as well as a reduced amount of carbohydrates and protein (Kasum, Jovanović, \& Ćirković, 2002). If the weight of the body is much higher than usual, it requires entering into the problem of regulating weight and its reduction to a limit values.

In relation to the mineral component it was found that the total mass of minerals in the body is from $4.89 \pm .99 \mathrm{~kg}$ with a reliability interval from 4.55 to $5.24 \mathrm{~kg}$, that the mineral part of bone mass (Osseous) is $4.00 \pm .83 \mathrm{~kg}$ with a reliability interval of 3.71 to $4.29 \mathrm{~kg}$. Percentage of the mineral part of bone mass relative to body mass is at the level of $4.86 \pm .24 \%$ (from 4.73 to $4.98 \%$ ), and observed through the BSI index with the average value of $.0486 \pm .0024$, on 1 kilogram of body weight in proportion there are 48.6 grams of bone tissue minerals (Table 2).

Tested sample of wrestlers had $49.71 \pm 8.73 \mathrm{~kg}$ mass of living cells in the body (BMC - Body Cell Mass) which is $60.74 \pm 2.32 \%$ representation in the body (Tables 1 and 2).

In the end, the average estimated body composition (Fitness SCORE) was $96.90 \pm 8.11$ points, with a range of reliability interval from 93.05 to 100.00 points.

Figure 1 shows the 4D model of body composition of tested wrestlers with the following model characteristics: in relation to the average body weight

\section{FIGURE 1}

4D model of body composition tested wrestlers.

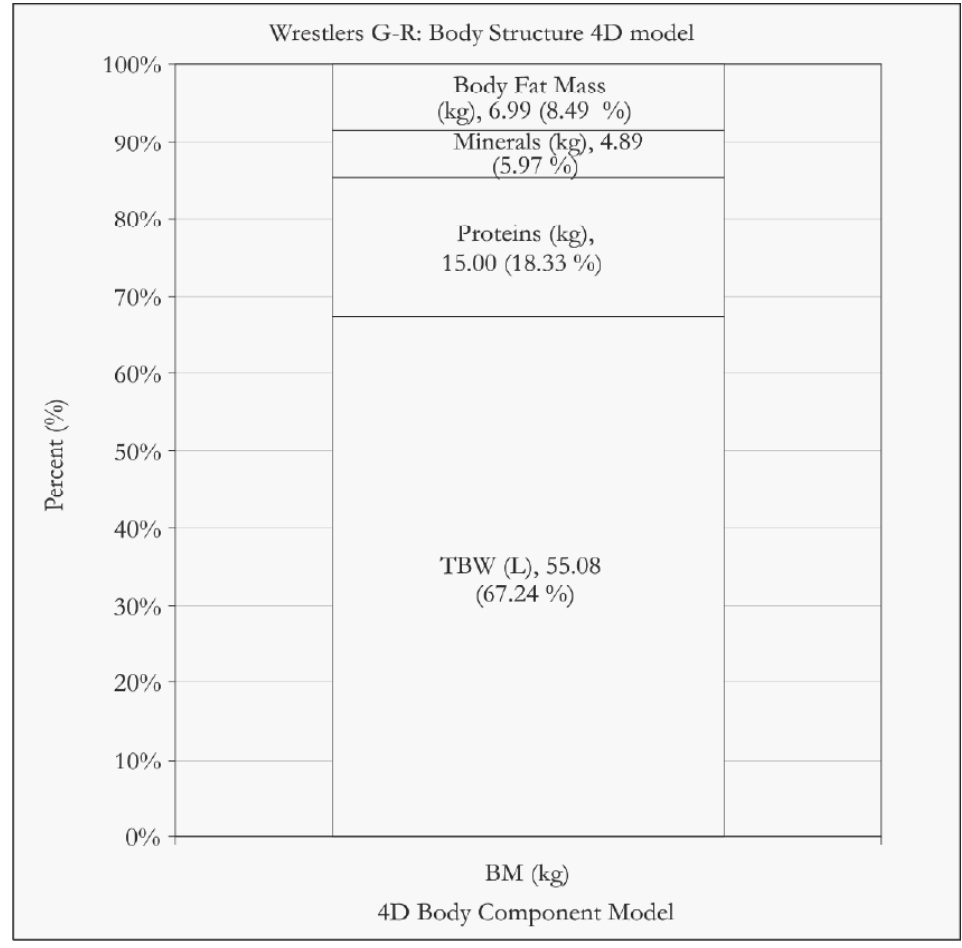


of wrestlers from the sample $-81.95 \mathrm{~kg}$, the water content is $55.08 \mathrm{~L}$ and $67.24 \%$, amount of proteins is $15.00 \mathrm{~kg}$ or $18.33 \%$, the mass of minerals is 4.98 $\mathrm{kg}$ or $5.97 \%$ and fat weight is $6.99 \mathrm{~kg}$ or $8.49 \%$.

\section{CONCLUSION}

Results of this study showed that quality wrestlers have the percentage of average fat in the body of $8.49 \%$ of the total body mass, with minimum and maximum values for total body mass at the level of $2.95 \%$ and $17.17 \%$, respectively with a reliability interval from 6.28 to $10.70 \%$. Bearing in mind the fact that in wrestling there are weight classes, larger amounts of fat are unnecessary ballast, which must be maximally reduced.

In contrast to adipose tissue, with wrestlers is very desirable to have high percentage of muscle tissue. Results of this study showed that with quality wrestlers, the percentage of lean body mass on average is $52.79 \%$ of the total body mass, with a minimum recorded values of $47.78 \%$ and a maximum value of up to $56.79 \%$ of the total body mass, i.e. with a confidence interval of 51.45 to $54.13 \%$. Bearing in mind the fact that in wrestling there are weight classes, aspiration of all wrestlers to have a greater percentage of muscle tissue cannot be realized by muscle hypertrophy. In fact, gain of lean muscle mass can even be a problem if the wrestlers are brought into a situation to change competitor category.

In any case, the amount of water is important information for the wrestlers. Excessive loss of fluids leads to dehydration of the body, and each dehydration leads to the loss of electrolytes. Results of this study showed that the average measure of hydration of quality wrestlers was at a level of $34.71 \pm 6.10$ liters of liquid content in the cells (ICW), $20.37 \pm$ 3.83 liters of liquid contents in the extracellular space $(\mathrm{ECW})$, and that the total amount of water in the body was at the level of $55.08 \pm 9.91$ liters (TBW). Measured amount of TBW was $67.24 \pm 2.51 \%$ of total body weight (TBW\%). Given variable had the characteristics of a very homogeneous size with a reliability interval of 65.61 to $68.88 \%$.

However, the most important result of this study is defining of generic (general) four-dimensional model (4D model) of body composition in a function of quality international-class wrestlers, which has the following characteristics: in relation to the average body weight of wrestlers from the sample - $81.95 \mathrm{~kg}$, the water content is $55.08 \mathrm{~L}$ or $67.24 \%$, amount of proteins is $15.00 \mathrm{~kg}$, or $18.33 \%$, mineral mass is $4.98 \mathrm{~kg}$ or $5.97 \%$ and fat weight is $6.99 \mathrm{~kg}$ or $8.49 \%$.

\section{ACKNOWLEDGMENT}

This study was a part of the program project funded by the Ministry of Science and Technology Development of the Republic of Serbia (no. III47015, 2011-2014).

\section{REFERENCES}

Аныш, А. С. (1999). ВАияние физических упражнений на мышщы [nfluence of physical exercise on muscles]. Неопубликкованный реферат. БАаговещенск: Амурский государственный университет.

Bajić, Z., Ponorac, N., Rašeta, N., \& Bajić, Đ. (2010). Uticaj fizičke aktivnosti na kvalitet kosti [Influence of physical activity on bone quality]. SportLogia, 6(1), 7-13. doi: 10.5550/sgia.1001007 Борисов, J. А., \& Туманян, Г. С. (1973). Обьем сердца и его зависимость от размеров тела у борцов [Volume of the heart and its dependence on body size in wrestlers]. ТПФК, 11, 37-40.

Buford, T. W., Rossi, S. J., Smith, D. B., O'Brien, M. S., \& Pickering, C. (2006). The effect of a competitive wrestling season on body weight, hydration, and muscular performance in collegiate wrestlers. The Journal of Strength \& Conditioning Research, 20(3), 689-692. doi: 10.1519/R-19955.1; doi: 10.1519/00124278200608000-00034

Deurenberg-Yap, M., Schmidt, G., van Staveren, W. A., Hautvast, J. G. A. J., \& Deurenberg, P. (2001). Body fat measurement among Singaporean Chinese, Malaysand Indians: acomparative study using a four-compartment model and different two-compartment models. British Journal of Nutrition, 85, 491-498. doi: 10.1079/BJN2000276; PMid: 11348564

Đorđević, A. (2005). Skidanje masnih naslaga kod rekreativaca [Fat loss for recreationists]. Sportska medicina, 5(3), 150-179.

InBody 720, The Precision Body Composition Analyzer, Manuel for Use, 1996-2008 Biospace Co., Ltd, Seoul, Korea. (2008).

Jagiełło, W., \& Kruszewski, A. (2005). Profil strojenia tela sbornoj komandy Polszi po klasiczeskoj borbe Profile body build Poland's national team in a classic wrestling]. In S. S. Jermakowi (Ed.), Fiziczeskoje wospitanije studentón tworczeskich specjalnostej (pp. 88-95). Charków, PL: HGADI (HHPI).

Jagiełło, W., \& Kruszewski, A. (2009). Morphological diversification of competitors training Greko-Roman style of wrestling. Archives of Budo, 5, 147-153. 
Jagiełł, W., Tkaczuk, W., \& Kruszewski, A. (2004). Morfofunkcjonalne aspekty efektiwnosti sorewnowatelnoj dejatelnosti sportsmenok, specjalizirujuszczichsja w wolnoj borbe [Morfofunctional aspects of efficacy of activity sportswomans in freestyle wrestling]. In S. S. Jermakowa (Ed.), Pedagogika, psychologia ta medikobiologiczny problemy fizicznogo wichowanija $i$ sportu (pp. 93-104). Charków, PL: HDADM (HHPI).

Kasum, G. (2001). Kritički osvrt na 48. Evropsko prvenstvo u rvanju grčko-rimskim stilom. [Critical review on the 48th European Championships in Greco-Roman wrestling] Firickea kultura, 55(1-4), 127-129.

Kasum, G., Jovanović, S., \& Cirković, Z. (2002). Problem regulisanja telesne težine kod mladih rvača [Problem of regulating body weight in young wrestlers]. Godisnjak, 11, 168-171.

Kasum, G., \& Obradović, Z. (2008). Efekti i uticaji trenažnog procesa na antropometrijski status u rvanju [Effects and impacts of the training process on the anthropometric status in wrestling]. In J. Babiak (Ed.), Prvi naucno - stručni medunarodni simpozijum "Efekti i uticaji razlicicitih modela trena:̌nog procesa na antropoloskei status sportista u borilackim sportovima" (pp. 23-27). Pančevo, RS: Pokrainski zavod za sport Novi Sad i SO Pančevo.

Kasum, G., \& Radović, M. (2009). Connection of some morphological characteristics of best wrestlers and their main scoring techniques. In S. Wlodzimierz and B. Jevtić (Eds.), 10th Sport Kinetics Conference Belgrade 2007 "New ideas in fundamentals of Human Movement: current issues and perspective" (pp. 287-295). Belgrade, RS: IASK.

Khani, M., Farokhi, A., Shalchi, B., Angoori, P., \& Ansari, A. (2011). The relationship of personality dimensions and self-regulation components to the success of Iranian boxers. Serbian Journal of Sports Sciences, 5(1-4), 21-28.
Мартиросов, Э. Г., \& Туманян, Г. С. (1974). Морфологические и функииональньге особенности боруов в связи со спортивныгми достинсениями [Morphological and functional features of the fighters in connection with sports achievements]. Вопросы антропологии. Москва, RU: МГУ.

Моргунов, Ю. А., Потратий, Р. С., \& Старкова, Е. С. (1985). Состав тела атлетов, занимающихся вольной борьбой [Body composition of athletes engaged in freestyle wrestling]. ТПФК, 4, 19-22.

Obradović, B., Jakšić, D., Matić, R., Milošević, Z., Bubanj, S., \& Bubanj, R. (2011). The correlation between anthropometric, motor and the variables for the evaluation of bone density. Facta universitatis - series: Physical Education and Sport, 9(3), 265-274.

Rupčić, T., Matković, B., Knjaz, D., Baščevan, S., \& Rodić, S. (2011). Differences in physiological load of the referees with concideration to the period of the basketball game. SportLogia, 7(1), 84-94. doi: 10.5550/sgia.120081.en.051R; doi: 10.5550/sgia.120081.se.047R

Schmidt, W. D., Piencikowski, C. L., \& Vandervest, R. E. (2005). Effects of A Competitive Wrestling Season on Body Composition, Strength, and Power in National Collegiate Athletic Association Division III College Wrestlers. The Journal of Strength \& Conditioning Research, 19(3), 505-508. doi: 10.1519/R-15014.1; doi: 10.1519/00124278200508000-00004

Станков, А. Г., КАимин, Б. П., \& Письмеский, И. А. (1984). Индивидуализачия подготовки бориов [ndividualization of fighters practice]. Москва, $\mathrm{RU}:$ Физкультура и спорт.

Yoon, J. (2002). Physiological profiles of elite senior wrestlers. Sports Medicine, 32(4), 225-233. doi: 10.2165/00007256-200232040-00002; PMid: 11929352

Received: November 1, 2012 Revision received: December 1, 2012 Accepted: December 23, 2012

Correspondence to: Goran Kasum, PhD Fakulty of Sports and Physical Education Blagoja Parovića 156 11000 Belgrade Serbia

Phone: 00381642710252 E-mail: goran.kasum@fsfv.bg.ac.rs 